\title{
Key Factors on Utilizing the Production System Design Phase for Increasing Operational Performance
}

\author{
Md Hasibul Islam ${ }^{(\triangle)}(\mathbb{D})$, Zuhara Chavez, Seyoum Eshetu Birkie (iD), \\ and Monica Bellgran (D)
}

KTH Royal Institute of Technology, 15181 Södertälje, Sweden

mhisla@kth.se

\begin{abstract}
Production system lifecycle includes phases ranging from concept pre-study to ramp-up and operations. Manufacturing companies often face challenges to reach operational performance targets during ramp-up time and operation phase. The design phase is considered crucial as major decisions related to the future production system are taken during this phase. There is an opportunity to utilize the production system design phase to improve the operational performance during both the ramp-up and operation phase. This research aims to identify the critical factors of the design process that affect the performance in the ramp-up and operational phase. A case study was conducted in a pharmaceutical company where a completed project of launching a new production line for a new product was followed in retrospect. Data were collected by conducting interviews with different members involved in the project and the production team on the shop floor. By qualitative data analysis, critical factors affecting the project's operational performance were identified; such as level of internal technical competency; involvement level of future line manager, operator and project sponsor within the project team; project team's competency; pre-study of the business case; time pressure to complete the project; expertise of product and process; organization's continuous improvement culture; and relationship with the supplier.
\end{abstract}

Keywords: Sustainable production $\cdot$ Production system design $\cdot$ Ramp-up · Factors $\cdot$ Production system design process

\section{Introduction}

Production systems design is one of the critical competencies for companies to achieve desired operational results [1]. For the last couple of decades, a lot of attention has been given by researchers and practitioners to improve the operational performance on the shop-floor to achieve the desired efficiency and output. Apart from disturbances during the operation phase, many manufacturing companies face economic losses due to low productivity concentrated in the ramp-up phase [2]. Introducing a new product in the market, integrating new manufacturing technologies for new products or existing products, often lead to different challenges associated with the ramp-up phase, such as low productivity, new technical problems, quality-related deviations [18]. Therefore, it 
is crucial to put attention to the design phase of a new production system/line or to the upgrading of an existing system, to comply with the challenges both during ramp-up and operation phase [3].

Manufacturing companies launch a new production system or upgrade the existing production system, such as assembly lines, to improve the capacity and/or operational performance [1]. In addition, there are many activities associated with the design process of a new production system, such as identify requirements, design the equipment, design layout and logistics flow and select equipment suppliers, that take years of time $[1,4]$. Though production system design teams usually face the pressure to reduce the time-to-volume period and deal with a lot of uncertainty, designing a robust production system is crucial in order to reduce disturbances during operation and ramp-up time $[3,5]$. Hence, utilizing the design phase of the complete production system life cycle offers the opportunity to achieve performance objectives during the later stages of the life cycle.

In practice, usually within a large manufacturing organization, activities of the designing production system process are handled by a separate team or department and are considered as a project [3]. Therefore, the team adopts project management concepts to carry out their functions, requiring the involvement of experts from various company departments like production, quality, health \& safety, maintenance, finance, etc., in some cases also adding equipment and raw material suppliers [3]. The design team needs to solve several challenges, such as specifying the requirements of the production equipment to align with practices like Lean and Green [6, 7], choosing the right equipment supplier, finishing the project within a short period of time and limited budget and supporting the learning process during ramp-up after installation of equipment [1]. Solving these tasks requires a standard procedure to perform the related activities and be able to deliver information effectively with strong collaboration among team members of different departments and equipment suppliers [3]. However, utilizing the potential of the design phase of the production system by considering challenges in later stages is often ignored. Therefore, this research aims at exploring how the design phase of the production system lifecycle could be utilized to increase the operational performance in the ramp-up and operation phase. In compliance with this aim, this paper will address the following research question:

RQ: What are the critical factors of the design process that affects the operational performance in the ramp-up and operational phase?

\section{Literature Review}

To search for existing literature within this specific research context, different terms"Production Equipment Acquisition", "Production system design", Factors AND "Production system design", Factors AND "Production Equipment Acquisition"- were used to search within articles title, abstract and keywords in scientific database- Scopus and Web of Science. Based on the found articles brief theoretical background relevant to this research are presented as follows. 


\subsection{Production System Design Process}

The production system design phase is a part of the lifecycle of the production system. A model of lifecycle of production system proposed by Wiktorsson [8] includes several phases- planning, design, realization or construction, start-up, operation, operation refinement, and finally termination or re-use. The activities in design stage has been elaborated in production system development framework presented by Bellgran [1] where the design phase is categorized in two stages; preparatory design and detailed design. In the preparatory design stage; by doing background study and pre-study the requirement specification is generated which act as input for the detailed design stage. In the detailed design stage, conceptual production system alternatives based on the requirement specification are generated, evaluated and finally, a detailed design is carried out of the chosen production system.

\subsection{Challenges and Factors of the Production System Design Phase}

There are several challenges associated with the production system design process mentioned in previous research. For instance, difficulties in coordinating the whole design process [9], lack of a systematic working structure [3], managing the project team with members from different specialized function [10], lack of well-defined objectives of the production system at the beginning [11], uncertainties in information flow between different stakeholders, and difficulties to align with business and manufacturing strategies [3].

Earlier research suggested remedies to the possible challenges in the design phase. For instance, strong collaboration with suppliers to design production equipment [4], proper information flow to manage uncertainty and equivocality with suppliers [12], assigning a contact with sufficient technical knowledge with suppliers [13], wellestablished design process with proper documentation, standardization and review system [13]. These remedies suggested by earlier researchers could be considered as factors that affects the performance during ramp-up and operation phase. However, based on the literature study, it has been observed that there is a lack of empirical studies on how to conduct the design process that targets the operational performance objectives already during the design phase. To the best of our knowledge, this subjected research question has not been specifically addressed in previous research. Therefore, considering this as a research gap, the research presented in this paper tries to identify factors during production system design phase that affect the ramp-up and operational phase and sets out to contribute to the theory building.

\section{Research Methodology}

This research has adopted an exploratory type case study method [14]. A case study approach allows to get rich and detail data that provides an in-depth understanding of a situation $[14,15]$. The case study was done in a pharmaceutical production company, located in Sweden, where a completed project (referred in this paper as Project-Y) of launching a new production line for a new product was followed in retrospect. 
The data was collected by reviewing project-related documents like- machine specifications, project charter, and conducting in total $7 \mathrm{~h}$ of interviews of six different professionals worked in the project. The interviewees were three project managers working in the project-Y consecutively, the process engineer, the line manager, and the current line manager. Interviews were recorded and later transcribed to text for further analysis. To validate the information collected from each interviewee, crucial information was cross-checked by other interviewees. The interview data was analyzed based on progressive coding techniques: Open Coding, Axial Coding and Selective Coding [16]. At first, based on the context, initial codes were generated during the open coding phase. The generated codes were categorized and used in axial coding phase to generate more meaningful information.

\subsection{Case Description of Project-Y}

In this company, production system design activities are carried out by a separate department. The company launched an internal program, referred in this paper as Program-X, to reduce its ramp-up time and to solve the challenges related to their production system design model. A finished Project-Y, was selected by the manager of Program-X to investigate and collect data that will assist them to set strategies to fulfil the objectives of Program-X.

The aim of the project-Y was to build a production line to supply an existing (not new) product to market at a specific time. The company used to supply the product for the market while being manufactured by a supplier. However, it was decided to shift to production in-house. The project started in the middle of 2015 and had a strict deadline to supply the commercial batches by mid-2017. It was a new product with a new production process from the production perspective, and the production department did not have the necessary expertise for some of the production processes. A team was formed to carry out the project comprising experts from different departments, such as investment, logistics, production, process, quality, health \& safety, etc.

\section{Result and Analysis}

Based on the analysis of the interview data, factors in the design process that affected the operation performance of the case project-Y is presented in following Table 1. 
Table 1. Factors impacting the performance in ramp-up and operation phase

\begin{tabular}{|c|c|c|}
\hline Factors & Elaboration of factors & $\begin{array}{l}\text { Reason/Impact during design, ramp-up } \\
\text { and operations phase in project-Y }\end{array}$ \\
\hline \multirow[t]{3}{*}{$\begin{array}{l}\text { Internal technical } \\
\text { competency }\end{array}$} & \multirow{3}{*}{$\begin{array}{l}\text { Strong Internal technical } \\
\text { competency to solve } \\
\text { deviations }\end{array}$} & $\begin{array}{l}\text { Suppliers competency was not adequate } \\
\text { to solve the machine-related deviations }\end{array}$ \\
\hline & & $\begin{array}{l}\text { Synchronize different equipment } \\
\text { supplied by different suppliers }\end{array}$ \\
\hline & & Eliminated false alarm in machines \\
\hline $\begin{array}{l}\text { Relationship with } \\
\text { supplier }\end{array}$ & $\begin{array}{l}\text { Strong relation with key } \\
\text { equipment suppliers }\end{array}$ & Facilitated redesigning of the equipment \\
\hline \multirow[t]{9}{*}{$\begin{array}{l}\text { Members involved } \\
\text { within Project team }\end{array}$} & \multirow{3}{*}{$\begin{array}{l}\text { Future line manager } \\
\text { involved since } \\
\text { beginning of project }\end{array}$} & $\begin{array}{l}\text { Focused on increasing automation to } \\
\text { minimize operators number }\end{array}$ \\
\hline & & $\begin{array}{l}\text { Developed machine specification } \\
\text { considering different lean principles }\end{array}$ \\
\hline & & $\begin{array}{l}\text { Tried to design layout and establish SOP } \\
\text { (standard operating procedure) to } \\
\text { minimize operator number }\end{array}$ \\
\hline & $\begin{array}{l}\text { Project sponsor actively } \\
\text { involved }\end{array}$ & $\begin{array}{l}\text { Showed direction quickly during project } \\
\text { considering financial issues }\end{array}$ \\
\hline & \multirow{5}{*}{$\begin{array}{l}\text { Operator involvement at } \\
\text { beginning of project }\end{array}$} & Skilled operators were recruited \\
\hline & & $\begin{array}{l}\text { Operators used Mock practice with } \\
\text { machines as training exercise }\end{array}$ \\
\hline & & $\begin{array}{l}\text { Operators were involved in developing } \\
\text { SOP from scratch }\end{array}$ \\
\hline & & $\begin{array}{l}\text { Operators were responsible to teach each } \\
\text { other operators }\end{array}$ \\
\hline & & $\begin{array}{l}\text { Strategy was to make operators skilled } \\
\text { enough to do small maintenance and } \\
\text { remove technician }\end{array}$ \\
\hline \multirow[t]{2}{*}{$\begin{array}{l}\text { Project team's } \\
\text { competency }\end{array}$} & \multirow{2}{*}{$\begin{array}{l}\text { Team members with } \\
\text { relevant knowledge and } \\
\text { expertise }\end{array}$} & $\begin{array}{l}\text { Acted proactively to reduce possible } \\
\text { uncertainties }\end{array}$ \\
\hline & & $\begin{array}{l}\text { First line manager had knowledge on } \\
\text { process, equipment, maintenance, and } \\
\text { operators' selection process }\end{array}$ \\
\hline \multirow{6}{*}{$\begin{array}{l}\text { Proper pre-study of } \\
\text { business case }\end{array}$} & \multirow[t]{6}{*}{ Poor business case } & No Pre-study was done about the project \\
\hline & & $\begin{array}{l}\text { Lack of proper information sharing to } \\
\text { project team }\end{array}$ \\
\hline & & $\begin{array}{l}\text { One machine was not regulated with ISO } \\
\text { standard }\end{array}$ \\
\hline & & Had to redesign some equipment \\
\hline & & Forced to work with particular suppliers \\
\hline & & Poor relation with a particular supplier \\
\hline \multirow[t]{3}{*}{ Time pressure } & \multirow{3}{*}{$\begin{array}{l}\text { Strict deadline to supply } \\
\text { market }\end{array}$} & Mock test performed during redesign \\
\hline & & $\begin{array}{l}\text { Test run before process validation was } \\
\text { cancelled due to time pressure }\end{array}$ \\
\hline & & $\begin{array}{l}\text { Lack of confidence on solving technical } \\
\text { issues related to machines }\end{array}$ \\
\hline
\end{tabular}


Table 1. (continued)

\begin{tabular}{l|l|l}
\hline Factors & Elaboration of factors & $\begin{array}{l}\text { Reason/Impact during design, ramp-up } \\
\text { and operations phase in project-Y }\end{array}$ \\
\hline $\begin{array}{l}\text { Product/process } \\
\text { expertise }\end{array}$ & $\begin{array}{l}\text { New product- never } \\
\text { produced before }\end{array}$ & $\begin{array}{l}\text { Lack of reliability on information } \\
\text { regarding quality deviation parameters }\end{array}$ \\
\cline { 2 - 3 } & $\begin{array}{l}\text { Lack of information on quality deviation } \\
\text { parameter }\end{array}$ \\
\cline { 2 - 3 } & $\begin{array}{l}\text { New equipment- never } \\
\text { worked with before }\end{array}$ & $\begin{array}{l}\text { Poor performance of machine after } \\
\text { installation }\end{array}$ \\
\hline $\begin{array}{l}\text { No previous knowledge about handling } \\
\text { the machines }\end{array}$ \\
\hline $\begin{array}{l}\text { Organization's } \\
\text { continuous } \\
\text { improvement } \\
\text { culture }\end{array}$ & $\begin{array}{l}\text { Mindset to continuous } \\
\text { improvement of existing } \\
\text { system }\end{array}$ & $\begin{array}{l}\text { Project team developed new way of } \\
\text { communication within project }\end{array}$ \\
\cline { 2 - 2 } & $\begin{array}{l}\text { Project team developed new way of } \\
\text { reviewing documents }\end{array}$ \\
\cline { 2 - 2 } & $\begin{array}{l}\text { All relevant units were involved in the } \\
\text { project }\end{array}$ \\
\hline
\end{tabular}

\section{Discussion}

Based on the factors (presented in Table 1), one of the factors was strong internal technical competency to solve technical issues associated with production equipment. Detecting and fixing technical issues with equipment is one of the major concern in ramp-up phase and company requires strong technical competency to solve them [17]. When designing a production system, it is very common to purchase different equipment from different suppliers, and fitting them together in an assembly line was one of the challenges mentioned during interviews. Therefore, strong internal technical competency was important not only to assist in solving technical issues during the ramp-up period, but also to assist the production system design team to select the desired equipment.

Another factor identified was the strong relationship with the equipment supplier that have been highlighted by previous researchers $[4,12]$. For the case project-Y, the company had strong relation with some suppliers which facilitated the reengineering process of some of the equipment where the design was modified jointly by supplier and production team. In contrary, the company had weak relationship with a particular equipment supplier which clearly affected the design process negatively. Therefore, this situation indicates that, lack of strong relationship with one equipment supplier could affect the whole design process, no matter how strong the relationship with other equipment suppliers.

How the design team was formed in terms of competency could be considered a crucial factor. As mentioned in the literature review, managing the production system design team from different functions/disciplines is a challenge, and deciding about the project team is hence an important question [1]. In this case project-Y, the future line manager, project sponsor and operators participated actively from the beginning of the 
project and their high expertise proved to be advantageous during the whole project. Therefore, high involvement level of production team, especially at early stage in production system design process, allows them to design the production system considering future operational perspective that usually impacts on the operational performance.

Apart from this, level of expertise on product and manufacturing process affects the design process. For the studied case project-Y, the product and related manufacturing process was new and the company had not produced the specific product line before. Therefore, due to lack of internal competency and knowledge about the production process for the product, it took some time to reach the quality level internally set as acceptable, to develop standard operating procedure and to learn about the different technical issues related to equipment. As product and process maturity level has already been highlighted as major issue during ramp-up [17, 18], it affect the design process as well.

For case project-Y, the project team had a strict deadline to finish the project and to comply with that test run of machines after the installation was shortened. This affected the training time and quality for the operators and technicians. As a consequence, in the operation phase production team had less confidence to fix technical errors with the machines and it affected the quality and technical availability of the products. Lack of training has been pointed as one of the challenges during the ramp-up period [17]. Therefore, time pressure to design a production system can have an impact on the performance during ramp-up and operation phase as it affects the training time and quality.

The organization's culture on continuous improvement is also found to be an important factor. In the case of project-Y, the team adopted several innovative approaches that could speed up the process, such as a new way of reviewing documents by the team members, new way of conducting a meeting to remain more attentive, involving other departments actively and providing freedom to the first line manager. It indicates their mindset to improve existing system which could be related to organizations culture on continuous improvement.

Finally, the proper pre-study of a business case for initiating a new production system affects the design process. For the case project-Y, several interviewees stated that the business case was poorly designed which affected some critical activities in the design process, such as selecting equipment supplier, defining machine specification, etc. Proper pre-study and business case development has been pointed out as crucial step for production system design process due to its impact during the operation phase [1].

\section{Conclusion, Practical Implication and Future Research}

The presented research contributes to existing knowledge on the management of production system design process by mainly addressing the important factors that need to be considered during the design phase of the production system so that the operational performance in the ramp-up and operation phase increases. The case study identified some of the factors based on investigation of a completed project in a pharmaceutical company. These factors are: strong internal technical competency; involvement level of future line manager, operator and project sponsor within the 
project team; project team's competency; proper pre-study of business case; time pressure to complete the project; expertise of product and manufacturing process; organization's continuous improvement culture; and relationship with equipment supplier.

As for practical implication, findings from this research could be utilized by practitioners by addressing the factors into their existing management system of the production system design process to upgrade it, and to develop their strategy for rampup as well. For instance, companies can chose to modify the involvement level of production team, to develop the internal technical competency rather relying on suppliers' expertise. Also this factors could be utilized as guideline for practitioners who wish to review or to develop their production system management process from scratch, especially for new companies.

For future research, as the factors presented here is based on a single case study, it is relevant to execute multiple case studies at the case company as well as at other companies to validate or modify the factors to establish general theory. In addition, different numerical or quantitative analysis method could be used to prioritize the factors which is missing in the current research. Furthermore, a framework of the management of production system design process could be developed to support the practical implications mentioned here.

\section{References}

1. Bellgran, M., Säfsten, E.K.: Production Development: Design and Operation of Production Systems. Springer, London (2010). https://doi.org/10.1007/978-1-84882-495-9

2. Viles, E., Bultó, R., Mateo, R., Jurburg, D.: Production ramp-up in European automotive production systems: a performance analysis. Prod. Plann. Control 1-18 (2020)

3. Bruch, J.: Management of design information in the production system design process. Doctoral dissertation, Mälardalen University (2012)

4. Rönnberg-Sjödin, D.: A lifecycle perspective on buyer-supplier collaboration in process development projects. J. Manuf. Technol. Manag. 24(2), 235-256 (2013)

5. Barton, J.A., Love, D.M., Taylor, G.D.: Design determines $70 \%$ of cost? A review of implications for design evaluation. J. Eng. Des. 12(1), 47-58 (2001)

6. Smith, L., Ball, P.: Steps towards sustainable manufacturing through modelling material, energy and waste flows. Int. J. Prod. Econ. 140(1), 227-238 (2012)

7. Yusup, M.Z., Wan Mahmood, W.H., Salleh, M.R., Mohd Yusof, S.A.: The adoption of lean and cleaner production-a preliminary study for malaysia manufacturing industry. Appl. Mech. Mater. 660, 949-953 (2014)

8. Wiktorsson, M.: Performance assessment of assembly systems: linking strategy to analysis in early stage design of large assembly systems (2002)

9. Cochran, D.S., Arinez, J.F., Duda, J.W., Linck, J.: A decomposition approach for manufacturing system design. J. Manuf. Syst. 20(6), 371-389 (2001)

10. Love, D.: The design of manufacturing systems. Int. Encycl. Bus. Manage. 4, 3154-3174 (1996)

11. Chryssolouris, G.: Manufacturing Systems: Theory and Practice. Springer, Heidelberg (2013)

12. Sjödin, D.R., Frishammar, J., Eriksson, P.E.: Managing uncertainty and equivocality in joint process development projects. J. Eng. Technol. Manag. 39, 13-25 (2016) 
13. Bruch, J., Bellgran, M.: Design information for efficient equipment supplier/buyer integration. J. Manuf. Technol. Manag. 23(4), 484-502 (2012)

14. Yin, R.K.: Case Study Research and Applications: Design and Methods. Sage Publications, Thousand Oaks (2017)

15. Eisenhardt, K.M.: Building theories from case study research. Acad. Manag. Rev. 14(4), 532-550 (1989)

16. Strauss, A., Corbin, J.: Basics of Qualitative Research Techniques. Sage Publications, Thousand Oaks (1998)

17. Surbier, L., Alpan, G., Blanco, E.: A comparative study on production ramp-up: state-of-theart and new challenges. Prod. Plan. Control 25(15), 1264-1286 (2014)

18. Almgren, H.: Pilot production and manufacturing start-up: the case of Volvo S80. Int. J. Prod. Res. 38(17), 4577-4588 (2000) 